\title{
Performance Laboratory as a Research Center for Lectures and Students
}

\author{
Taufik \\ Sport Science Depaterment \\ Universitas Negeri Malang \\ Malang, Indonesia \\ taufik.fik@um.ac.id
}

A.M Wulandari

Sport Science Depaterment

Universitas Negeri Malang

Malang, Indonesia

\author{
Moch. Yunus \\ Sport Science Depaterment \\ Universitas Negeri Malang \\ Malang, Indonesia \\ moch.yunus.fik@um.ac.id
}

\section{E.Z I'tamada}

Sport Science Depaterment Universitas Negeri Malang

Malang, Indonesia

\author{
N.R Fadli \\ Sport Science Depaterment \\ Universitas Negeri Malang \\ Malang, Indonesia \\ nurrul.riyad.fik@um.ac.id
}

\begin{abstract}
The purpose of this research and development is to determine the need for the development of Achievement Laboratory models that follow the characteristics and groups of scientific fields in the Faculty of Sports Science. Furthermore, developing the Performance Laboratory model which consists of several divisions, developing the divisions to become a forum for lecturers and students to collaborate in research and community service. The research method used is development research methods. Research and development procedures, needs analysis, expert validation tests, group trials, product improvement, and final products. The research subjects were lecturers and students of the Sports Science Faculty. The results of the validation test for sports management were $84.56 \%$ and 84.46 , then the results of the small group trial were $80.94 \%$. and the results of large group trials 84.6. These results indicate that the Performance Laboratory model can be used and applied. The Achievement Laboratory is a sports laboratory model which is expected to improve research and lecturer service. Laboratory as an incubator for students to study entrepreneurship in the sports industry. The results of expert validation and group trials show that this laboratory model can be applied in the Faculty of Sports Science.
\end{abstract}

Keywords-Performance Laboratory, Incubator, start-up.

\section{INTRODUCTION}

The autonomy and decentralization of education in Indonesia requires all state universities to be transformed into state-owned legal entities (BHPT). In this new form, universities are expected to be able to manage funds for the provision of education independently. Autonomy also means that with this new form, universities must independently finance the various needs that are needed, including finding alternative costs other than subsidies from the government which have been their mainstay. Several ways were taken to meet the needs of higher education institutions and at the same time improve the quality of education, among others, by providing facilities from the Ministry of National Education to obtain program a competitive block grant, funded by funds from within and outside the country. Based on experience so far, this program can only be achieved by large tertiary institutions whose funding sources meet the requirements. Not all of them can achieve the programs for small and medium universities which are dominant in number in Indonesia.

The very rapid development of science in the 4.0 era has triggered developing countries and developed countries to compete to be at the forefront of the development of science. The digital revolution or also known as the 4th industrial revolution has had a tremendous impact on human life. The Fourth Industrial Revolution required a new vision of living together, including a new vision for development, education and culture. So that the new vision of curriculum and learning in tertiary institutions must adapt and be able to adapt to the changing times that are increasingly erratic and can produce a generation that has the capability to create jobs, not job seekers.

Sports science has become a rapidly developing part of science, this is marked by the revolution in sports from achievement sports to industrial sports. Indonesia is a developing country that has a big potential role in the development of sports in Asia and the world, but this huge potential is only accommodated by the sports committee and the Indonesian education office, there is no place developed by the state to bridge it. cooperation between sports practitioners and academics, so that knowledge about sports cannot be applied in the development of sports in Indonesia. Changes in 
the higher education curriculum at the State University of Malang have caused capability to no longer be a work profession so that a laboratory for lecturers and students is needed that can be used for research and service to improve the capabilities of lecturers and students. The concept of themodel Performance Laboratory (TO Bompa, Di Pasquale, \& Cornacchia, 2013) which researchers will develop as a faculty flagship program, will become an incubator for students to develop their abilities, as well as a place for research and lecturer service.

Sport has become an inseparable part of a country, sport is an event to show the sovereignty of a country, not only that sport can also improve the micro economy (Kristiyanto, 2012) to alleviate poverty. So that it takes the management of sports institutions in higher education as an incubator of student business ideas in the field of sports. So that universities have an important role in increasing the capability of students to become entrepreneurs in the sports industry. Higher education also has a very important role (Mahendra, 2007) in the development of long-term athletes applied in European and European countries, long-term athlete development (LTAD) written (Balyi, Way, \& Higgs, nd) LTAD in training design , competency, and recovery programs to guide coaches, athletes, parent organizations, parents and all sports communities involved in planning, training, competition, and recovery. Long-term athlete development is the best program vision as an effort to increase high achievement chronologically with agebased growth and development (Robertson and way).

The business incubator has an incubation process that plays a role in helping tenants with the aim that tenants can solve their problems well so that the spirit to compete or compete in business can survive and develop rapidly (Siregar, Gustina, Andriany, Dewi \& Bismala, 2019). Not only in the field of education but in the field of sports can also develop incubators that can develop the potential that exists in the field of sports. One of them is the Performance Laboratory (PL) which is located at the Faculty of Sport Sciences, State University of Malang, which is also a forum that can channel the existing potentials for both lecturers and students. The incubator is expected to be a start-up in doing business.

Business Incubator for Higher Education, a part from being expected as a medium for training initiation and business access, is also expected to have multiple functions, namely that it can be used as a forum for entrepreneurship education for students, practical field work and also as afacility company teaching that has been weak so far. in Indonesia. . Therefore, apart from being an income-generating unit, Inbis is also able to support teaching and learning process facilities, so that the education system can produce professional graduates. The Higher Education Business Incubator is a business incubation platform that is expected to be able to develop businesses in the community and universities, in the form of facilities and preparation of university business units that lead to profit centers.

\section{METHOD}

This type of research uses development research methods that use research and development methods according to Borg and Gall (1983). The development method should include the development model and development procedures.

\section{A. Research and Development Procedure}

Modification of theresearch and development procedure model

Borg and Gall's, the researcher uses an 8-step development procedure, the explanation

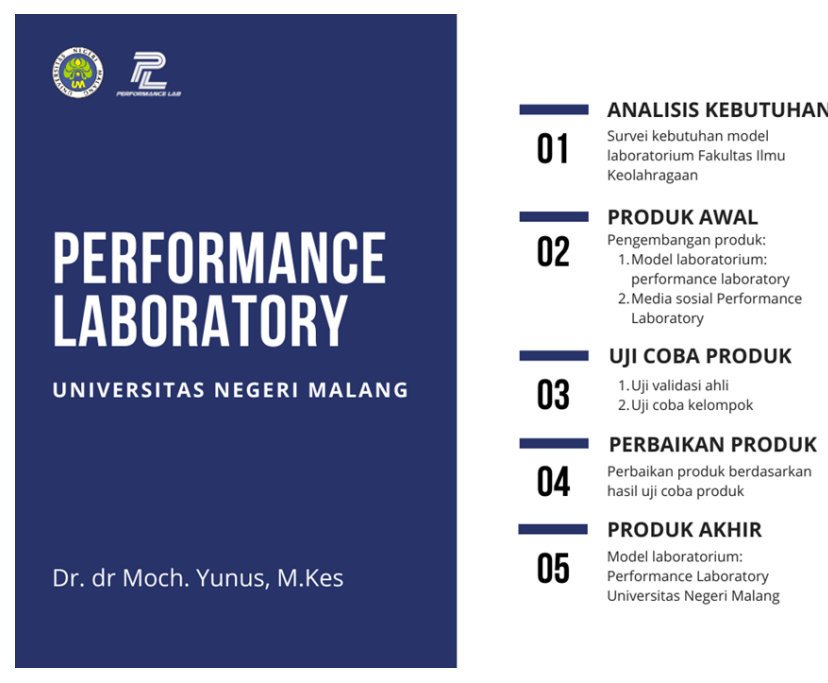

Figure 1.Borg and Gall's (1983) research and development procedure

\section{B. Research Subjects}

Lecturer in Physical Education and Health, Lecturer in Sports Science, Lecturer people in Sports Development, Physical Education and Health 80 student, Sports Science 80 student, Physical Education 80 student and Public Health Sciences 80 student

\section{Research Instruments}

- The observation sheet is used for observation of zero participation by observing the learning conditions in the management and observation laboratory participatory while observing the process of small group trials and large group trials as well as testing the effectiveness of the product.

- The next instrument used in this study was a questionnaire. Questionnaires are written questions that are used to obtain information about athletes' ratings during small and large group trials and to obtain information from experts..

\section{Data Analysis}

Based on the type of data obtained, data processing in this study uses a quantitative approach and a qualitative approach.

- Quantitative Approach, Analysis of product trial data using percentage descriptive analysis techniques. Data obtained from the results of expert testing and group trials. Data analysis with this approach means that each analysis is adjusted to the approach used, only to find out the percentage $(\%)$ 
- Qualitative Approach in general, the data analysis process includes data reduction, data categorization, synthesis, and ending with the preparation of working hypotheses.

\section{RESULTS AND DISCUSSION}

\section{A. The Results of needs analysis}

analysis were obtained through interviews with lecturers who used laboratories and observations of learning using laboratories at the Faculty of Sport Science, State University of Malang, observation, and evaluation of laboratory management are presented in Table I

TABLE I The Results of needs analysis

\begin{tabular}{|c|c|}
\hline Subjek & Data \\
\hline Lecture & $\begin{array}{l}\text { - The use of laboratory is still only for certain lectures } \\
\text { - The laboratory at the Faculty of Sports Science is still } \\
\text { independent } \\
\text { - Access to laboratory use by students is limited only during } \\
\text { lectures. }\end{array}$ \\
\hline Student & $\begin{array}{l}\text { - Students still have difficulty getting access to laboratory } \\
\text { use } \\
\text { - Students get less than optimal service in the laboratory, } \\
\text { because there is no report yet }\end{array}$ \\
\hline
\end{tabular}

\section{B. The results of the evaluation of sports management}

Expert Sport Management, Dra. Sulistyorini, M.Pd, Lecturer in Sports Management of FIK State University of Malang, the product test process was carried out on June 20-25 2020 at FIK State University of Malang, the product test process took place 4 times because the revised results were based on expert advice and input was consulted again to the expert. . The results of the evaluation of sports management experts are presented in Table II

TABLE II The results of the evaluation of sports management

\begin{tabular}{|l|c|c|c|}
\hline \multicolumn{1}{|c|}{ Component } & $\begin{array}{c}\text { Maximum } \\
\text { Score }\end{array}$ & Results & Percentage \\
\hline Laboratory performance profile & 48 & 41 & 85 \\
Video on youtube channel laboratory & 48 & 40 & 83 \\
performance & 48 & 41 & 85 \\
Performance laboratory website & 48 & 41 & 85 \\
ebook Physical Exercise & $\mathbf{2 4 0}$ & $\mathbf{2 0 4}$ & $\mathbf{8 4 . 5 6}$ \\
\hline Total & & & \\
\hline
\end{tabular}

Based on table II, the results of expert evaluation are obtained with a percentage of $84.56 \%$. In addition to evaluation based on quantitative data, the expert also provides input based on qualitative data, namely as follows:

- The product presentation systematics are adjusted to the presentation of development products so that the product is easier to read and use.

- A theoretical study plus a study of training.
The conclusion from the results of the initial evaluation of the product expert is feasible for field trials with revisions as recommended.

Sports Management Expert, Dr. Imam Hariadi, M.Kes. Lecturer of FIK State University of Malang, the product trial process was carried out on June 20-25 at the Faculty of Sport Science, State University of Malang. The results of the evaluation of sports management experts are presented in Table III

TABLE III The results of the evaluation of sports management

\begin{tabular}{|l|c|c|c|}
\hline \multicolumn{1}{|c|}{ Component } & $\begin{array}{c}\text { Maximum } \\
\text { Score }\end{array}$ & Results & Percentage \\
\hline Laboratory performance profile & 48 & 41 & 85 \\
Laboratory youtube channel & 48 & 40 & 83 \\
performance videos & 48 & 40 & 85 \\
Laboratory website performance & 48 & 41 & 85 \\
Exercisephysical ebook & $\mathbf{2 4 0}$ & $\mathbf{2 0 3}$ & $\mathbf{8 4 . 4 8}$ \\
\hline Total & & & \\
\hline
\end{tabular}

Based on table III the results of the evaluation of sports management obtained a percentage of $84.48 \%$. In addition to quantitative-based data evaluation, the expert also provides input based on qualitative data, namely as follows:

- Laboratory Profile Performance of additional services offered

- It is better if the exercise book is printed so that it can be read immediately

- The conclusion from the results of the initial product expert evaluation is feasible for field trials with revisions as recommended.

\section{Field Trial}

Results Field trial results obtained through small group testing and large group testing, the trial process is intended to get responses from research subjects to products developed by researchers. Collecting data using a questionnaire, the data obtained is quantitative. The results of small group trials Small group trials were conducted on July 1-3, the PL study of State University of Malang, as many as 80 students of the Faculty of Sports Science were tested, the information on the results of small group trials obtained by using a questionnaire is presented in Table IV.

TABLE IV Small Group Test Results

\begin{tabular}{|l|c|c|c|}
\hline \multicolumn{1}{|c|}{ Component } & $\begin{array}{c}\text { Maximum } \\
\text { Score }\end{array}$ & Results & Percentage \\
\hline Laboratory performance profile & 1920 & 1577 & 80.52 \\
Laboratory youtube channel & 1920 & 1546 & 80.62 \\
performance videos & 1920 & 1548 & 81.45 \\
Laboratory website performance & 1920 & 1564 & 80 \\
Exercisephysical ebook & 9600 & 7721 & 80.94 \\
\hline Total & &
\end{tabular}

Based on table 4 the results of the small group trial obtained a percentage of $80.94 \%$. In addition, to record the 
trial process of a small group of researchers making observations, the results of these observations are as follows:

- The overall trial implementation went well because the subjects were cooperative and enthusiastic to follow.

- The concept of the performance laboratory of the State University of Malang can be understood by students

- Positive trends can be seen by accessing the Performance Laboratory website and YouTube channel.

- Fill out a questionnaire after a positive trend.

The final conclusion from small group trials based on test result data and field notes, group tests can be continued to large group trials.

The Results of large group trials Large group trials were conducted on 8-10 August 2020, the process of large group trials was carried out 3 times, the trial subjects totaled 160 students, information on the results of large group trials was obtained using a questionnaire, the results of group trials Table $\mathrm{V}$

TABLE V Large Group Trial Results

\begin{tabular}{|l|c|c|c|}
\hline \multicolumn{1}{|c|}{ Component } & $\begin{array}{c}\text { Maximum } \\
\text { Score }\end{array}$ & Results & Percentage \\
\hline Laboratory performance profile & 3840 & 3354 & 87.34 \\
Laboratory youtube channel & 3840 & 3228 & 84.81 \\
performance videos & 3840 & 3257 & 85.81 \\
Laboratory website performance & 3840 & 3149 & 82 \\
Exercisephysical ebook & 19,200 & 16,280 & 84.79 \\
\hline Total & &
\end{tabular}

Based on table $\mathrm{V}$, the results of large group trials obtained a percentage of $84.79 \%$. In addition, to record the trial process of a large group of researchers making observations, the results of these observations are as follows:

- The overall trial implementation went well because the subjects were cooperative and enthusiastic to follow.

- The concept of the performance laboratory of the State University of Malang can be understood by students

- Fill out a questionnaire after a positive trend.

The final conclusion of the large group trial based on the results of the trial and field notes, product testing can be continued to test the effectiveness of the product.

Higher education institutions that have business incubators have an impact on improving the learning system, perceptions, activities and organizational effectiveness as well as creating synergies and understanding the Tri Dharma of Higher Education in an integral manner. In its development, universities must be able to see that the factors in developing a technology-based business are institutions that are ready to be able to encourage and provide services and assistance to students in developing startups, these institutions are called business incubators (Jaya, Mardi Arya, Ferdiana, Ridi \&
Fauziati)., 2017). The model for the Inbis tertiary institution to be developed at least has the following components: (1) Name of Inbis; (2) Inbis 'position in the University's statute, Inbis' internal organizational structure (legality aspects); (3) Vision, mission and objectives; (4) The facilities that must exist; (5) Inbis working mechanism (internal and external); (6) Target audience inside and outside the university; (7) funding sources for Inbis; (8) Strategic plan and design of business service facilities; (9) Network between Inbis and business people; (10) Network with local and central government; (11) Internal monitoring and evaluation system. The working mechanism of the Inbis College consists of various elements, namely; (1) external working mechanisms in the Inbis organization, (2) working mechanisms with various university organizational structures (3) working mechanisms with tenants (4) working mechanisms with fellow inbis (inbis associations) (5) working mechanisms with inbis institutions, and ( 6) working mechanism with central and local government agencies.

The performance laboratory is a facility owned by the Faculty of Sport Science, State University of Malang. Performance Laboratory is a fitness center that functions as a fitness center, a place for research between lecturers and students and collaborates with parties involved in sports such as KONI, DISPORA and others both in Malang City itself and even Batu City. Activities that can be carried out are in the form of improving education and achievements in the field of sports. In the form of education, students and lecturers can interact directly and can use the fitness equipment contained in the OT and can conduct joint research and improve achievement, students can train their fitness using the facilities found in OT. Not only improving the quality of education and achievement of FIK UM students, PL itself also collaborates with KONI or those involved in sports in improving the quality of its athletes with the facilities and knowledge possessed by the PL administrators themselves.

\section{CONCLUSION}

Business incubators play an important role for Higher Education in encouraging student creativity and innovation in entrepreneurship. Thus, the performance of higher education can be seen in developing startups related to Tridharma as an example of community service. In Higher Education provides aconcept link and match which aims to make students comfortable and easy to follow learning in business incubators. Performance is one of the incubators at the Faculty of Sports Science that can develop the potential of students and lecturers in various activities such as research, learning and achievement which have quite good usage facilities. The Achievement Laboratory is a sports laboratory model which is expected to improve research and lecturer service. Laboratory as an incubator for students to study entrepreneurship in the sports industry. The results of expert validation and group trials show that this laboratory model can be applied in the Faculty of Sports Science. 


\section{ACKNOWLEDGMENT}

Researchers would like to thank the

- Rector of the Universitas Negeri Malang who gave the 2020 PNBP research grant

- Organizer of the International Conference Sports Sciences and Health (ICSSH) Faculty of Sport Science State University of Malang

- Instructor Performance Laboratory

\section{REFERENCES}

[1] Balyi, I., Way, R., \& Higgs, C. (n.d.). (2015) Long Term Athlete Development:Human Kinetics Champaign

[2] Bompa, T., \& Carrera, M. (2015). Periodization training for sports: Human Kinetics Champaign. Retrieved from https://www.worldcat.org/title/periodization-training-forsports/oclc/921225928\&referer=brief_results

[3] Bompa, T. O., Di Pasquale, M. G., \& Cornacchia, L. (2013). Serious strength training.

[4] Industri Mikro Olahraga*. Jurnal Ekonomi Pembangunan: Kajian Masalah Ekonomi Dan Pembangunan, 12(2), 200 https://doi.org/10.23917/jep.v12i2.193

[5] Mahendra, A. (2007). Pentingnya Olahraga Di Perguruan Tinggi. Seminar Nasional Temu Ilmiah, (November), 1-1

[6] Jaya, Mardi Arya, Ferdiana, Ridi \& Fauziati, S. (2017). Analysis of Success Factors for Digital Startups in Yogyakarta. SNATIVE.

[7] Kristiyanto, A. (2012). Penguatan Kebijakan Publik Usaha Pengentasan Kemiskinan Melalui Pengembangan

[8] Siregar, Gustina, Andriany, Dewi \& Bismala, L. (2019). Inwall Tenant Incubation Program at the Center for Entrepreneurship, Innovation and Business Incubator at the Muhammadiyah University of North Sumatra. National Seminar on Entrepreneurship, Muhammadiyah University of North Sumatra. 